УДК 349.3

DOI https: / / doi.org/ 10.32837 / yuv.v0i3.1963

\author{
О. Сорока, \\ здобувач кафедри правознавства \\ юридичного факультету \\ Східноукраїнського національного університету імені Володимира Даля
}

\title{
ПОНЯТТЯ ТА ОЗНАКИ СОЦІАЛЬНОГО СТРАХУВАННЯ ВІД НЕЩАСНИХ ВИПАДКІВ ТА ПРОФЕСІЙНИХ ЗАХВОРЮВАНЬ НА ВИРОБНИЦТВІ
}

\begin{abstract}
Постановка проблеми. Конституційне визнання людини, іï прав і свобод найвищою цінністю, проголошення України правовою соціальною державою висувають особливі вимоги до правового регулювання відносин у соціальній сфері, його якості й ефективності. Соціальне забезпечення має виняткове значення для добробуту громадян, працівників, їхніх сімей і всього суспільства у цілому. Право на соціальний захист посідає важливе місце серед інших прав людини та є одним із засобів досягнення злагоди, сприяє соціальному миру. Воно $€$ невід'ємною частиною соціальної політики держави й відіграє суттєву роль у недопущенні зниження рівня життя населення.
\end{abstract}

Одним із найважливіших за значимістю об'єктів соціального захисту громадян $€$ їхнє здоров'я, що багато в чому визначає міру їх адаптації до економічної ситуації, що зазнає постійних змін. Не випадково ст. 49 Конституції України та Преамбула Основ законодавства України про охорону здоров'я право на охорону здоров'я визнають природним невід'ємним і непорушним правом кожного. Суспільство й держава, відповідальні перед сучасним і майбутнім поколінням за рівень їхного здоров'я, забезпечують у діяльності держави пріоритетність охорони здоров'я, поліпшення умов праці, навчання, побуту й відпочинку насе- лення, розв'язання екологічних проблем, удосконалення медичної допомоги i запровадження здорового способу життя. Вагому роль у цьому покликано відіграти загальнообов'язкове державне соціальне страхування від нещасних випадків та професійних захворювань на виробництві.

Мета статті - проаналізувати погляди науковців та вітчизняне законодавство щодо поняття та характерних ознак загальнообов'язкового державного соціального страхування внаслідок нещасних випадків та професійних захворювань на виробництві, на підставі чого зробити відповідні висновки.

Аналіз останніх досліджень. Питання соціального страхування були предметом дослідження таких науковців, як В.М. Андріїв, Д.В. Божко, Н.Б.Болотіна, І.О. Гуменюк, О.Л. Кучма, О.В. Москаленко, В.I. Прокопенко, O.I. Процевський, С.О. Сільченко, C.M. Синчук, I.M. Сирота, Б.I. Сташків, О.В. Тищенко, Л.П. Шумна, M.M. Шумило, О.М. Ярошенко та ін.

Виклад основного матеріалу. Для більш детального дослідження загальнообов'язкового державного соціального страхування внаслідок нещасних випадків та професійних захворювань на виробництві наведемо наукові позиції вчених щодо тлумачення поняття «соціальне страхування». Як зазначає Д.В. Карамишев, соціальне страхування у класичному 
розумінні передбачає захист на випадок виникнення непередбачуваних ситуацій, вирішити які самостійно або дуже складно, або взагалі неможливо [1, с. 4]. Соціальне страхування, як уважає С.О. Сільченко, не лише захищає працюючих, а й служить механізмом суспільних інвестицій, доходи від яких повертаються у вигляді поліпшення якості життя населення, стабільності суспільства, формування спонукальних мотивів до праці, освіти й підвищення кваліфікації. Воно стало важливим засобом досягнення соціальної злагоди в суспільстві, запобігання й зниження рівня бідності. Право працюючих на це страхування набуло значення одного 3 найважливіших прав людини і громадянина [2, с. 78]. Своєю чергою, I.О. Гуменюк соціальне страхування визначає як провідну організаційно-правову форму соціального забезпечення, яка гарантує особам право на соціальне забезпечення і профілактику соціального (страхового) ризику за рахунок страхових коштів. Система соціального страхування - це складова частина системи соціального забезпечення, сукупності правових, економічних, організаційних заходів щодо забезпечення реалізації застрахованою особою (або членами іï сімі) права на матеріальне забезпечення та соціальне обслуговування, на умовах та в розмірах, передбачених законом чи договором про соціальне страхування [3, с. 9].

Одну 3 перших спроб дати системну відповідь на запитання, у чому ж полягає зміст поняття «соціального страхування», зробив свого часу М.О. Вігдорчик. Дослідник висловив міркування, що порівняно iз загальними видами страхування соціальне має особливості, властиві його об’єкту й колу осіб, які беруть участь у ньому. Спеціальний характер об'єкта соціального страхування випливає насамперед із причин, що зумовили виникнення соціального страхування як окремого інституту. Цими причинами стало підвищення ризику втрати робітником заробітної плати внаслідок тимчасової непрацездатності, нещасного випадку, безробіття тощо. Первинним (основним) об'єктом соціального страхування став саме ризик утрати заробітку. Цей об'єкт свого часу був новим для інституту страхування, хоча ризики, які зумовлювали, зокрема, і втрату заробітку, були здавна відомі таким видам особистого страхування, як страхування життя, медичне, від нещасного випадку та ін. Фахівець пропонує розглядати це явище як сукупність усіх тих форм і видів страхування, які мають на меті боротьбу 3 незабезпеченістю широких верств населення [4, с. 18-21].

До характерних ознак соціального страхування С.Г. Стеценко, В.Ю. Стеценко, Я.М. Шатковський відносять такі: (а) поєднання інтересів суспільства й окремої людини, оскільки воно заінтересоване в забезпеченні гідного мінімально необхідного рівня життя кожного його представника, а окремий індивід - у компенсації або мінімізації наслідків зміни свого матеріального (соціального) становища, що настали внаслідок страхового випадку; (б) джерелом фінансування соціального страхування виступає спеціальний позабюджетний фонд; (в) страхова виплата в рамках цього явища не зумовлена розміром страхового внеску; (г) страхові ризики, від настання яких здійснюється соціальне страхування, мають соціально значущий характер, тобто великомасштабні масові наслідки; (г) це явище охоплює тільки економічно активне населення, тобто працююче, отже, розмір страхових виплат має певну залежність від розміру страхового внеску [5, с. 18-19].

Отже, під соціальним страхуванням слід розуміти систему відносин між застрахованою особою, страхувальником і страховиком, що полягають у наданні застрахованій особі за рахунок соціальних страхових фондів, котрі формуються шляхом сплати 
страхових внесків, матеріального забезпечення в разі хвороби, повної, часткової або тимчасової втрати працездатності, втрати годувальника, безробіття з незалежних від неї обставин, старості та в інших випадках, передбачених законом.

В Основах законодавства України про загальнообов'язкове державне соціальне страхування [6] та Законі України «Про загальнообов’язкове державне соціальне страхування» [7] закріплено такі види соціального страхування: (1) у зв'язку з тимчасовою втратою працездатності; (2) від нещасного випадку на виробництві та професійного захворювання, які спричинили втрату працездатності; (3) медичне.

Завданням соціального страхування від нещасних випадків на виробництві та професійних захворювань, які спричинили втрату працездатності, є проведення профілактичних заходів, спрямованих на усунення шкідливих, небезпечних виробничих чинників; запобігання нещасним випадкам на виробництві, іншим випадкам загрози здоров'ю застрахованих, викликаних умовами праці; відновлення здоров'я та працездатності потерпілих на виробництві; відшкодування шкоди, пов'язаної 3 утратою застрахованими особами заробітної плати або відповідної іï частини під час виконання трудових обов'язків, надання їм соціальних послуг у зв'язку з ушкодженням здоров'я, а також у разі їх смерті здійснення страхових виплат непрацездатним членам їхніх сімей.

Зміст поняття «страхування від нещасних випадків та професійних захворювань на виробництві» у наукових дослідженнях розкривається по-різному: як фінансовий інструмент захисту особистих інтересів громадян у разі настання нещасних випадків на виробництві; відшкодування матеріальної та моральної шкоди застрахованим і членам їхніх сімей; підтримка рівня сімейних доходів у разі настання страхових випадків; вид страхового захисту працівників; витрати, пов'язані з негативним впливом на здоров'я; надання фінансової допомоги застрахованим у разі настання страхових подій тощо. Приміром, В.Д. Базилевич страхування від нещасних випадків на виробництві визначає як ризикове страхування, зміст якого полягає у виплаті відповідних грошових відшкодувань, зумовлених страховим випадком, а також зниженням доходів застрахованої особи, зумовленим нещасним випадком - несподіваною, непередбачуваною подією, що виникла всупереч волі людини, наслідком якої є ушкодження здоров'я або смерть [8, с. 136].

Відповідно до ст. 3 Закону України «Про загальнообов'язкове державне соціальне страхування», загальнообов'язкове державне соціальне страхування від нещасних випадків та професійних захворювань на виробництві здійснюється за принципами: державних гарантій реалізації застрахованими особами своїх прав; формування та використання страхових коштів на засадах солідарності та субсидування; диференціаціі розміру виплати допомоги залежно від страхового стажу; цільового використання коштів соціального страхування та ін. Таке страхування забезпечує попередження та відповідне реагування на наслідки нещасних випадків і може здійснюватися в різних формах: бути добровільним або обов'язковим, здійснюватися на комерційній основі чи бути державним.

Отже, загальнообов'язкове державне соціальне страхування від нещасних випадків та професійних захворювань на виробництві є частиною державної системи соціального захисту населення, здійснюване у формі страхування, за допомогою якого держава забезпечує соціальний захист, охорону життя та здоров'я громадян під час їхньої трудової діяльності, сприяє підвищенню ефективності їх соціального захисту в умовах існуючих професійних ризиків. 
Загальнообов'язковому державному страхуванню від нещасних випадків та професійних захворювань на виробництві притаманні такі ознаки: (a) є певним захистом від настання небажаних ризиків чи наслідків; (б) є гарантією закріпленого в ст. 46 Конституції України права на соціальний захист; (в) є державним, тобто порядок, умови здійснення визначаються i регулюються державою та не можуть змінюватися на розсуд сторін, як це може бути в приватному страхуванні; (г) охоплює конкретну сферу, а саме трудову діяльність. Страхування від нещасних випадків та професійних захворювань на виробництві невіддільне від трудової діяльності та може здійснюватися лише у разі впливу на працівника небезпечного виробничого фактору чи середовища, що сталися у процесі виконання ним трудових обов'язків або пов'язаних із трудовими, унаслідок яких заподіяно шкоду здоров'ю або настала смерть; (г) переслідує певну економічну функцію, що полягає у створенні необхідних умов для відтворення трудових ресурсів; (д) обов'язковість, тобто особи, які визначені законом, повинні сплачувати внески на загальнообов'язкове соціальне страхування.

Своєю чергою, M.I. Боднарук указує також на таку ознаку соціального страхування, як імовірність, яка полягає у тому, що попередньо неможливо точно визначити сторін і момент настання страхового випадку. Цільова ознака соціального страхування полягає у тому, що відповідний фонд використовується лише за цільовим призначенням [9, с. 301].

Також слід зазначити, що Закон України «Про загальнообов'язкове соціальне страхування» пов'язує можливість здійснення страхування не лише у разі настання страхового випадку, тобто нещасного випадку на виробництві, що спричинили застрахованому професійно зумовлену фізичну чи психічну травму, а й зі страховим ризиком, тобто 3 певними обставинами, унаслідок яких може статися нещасний випадок чи професійне захворювання. При цьому простежується певна невідповідність у чинному законодавстві, а саме ч. 1 ст. 36 Закону передбачає, що страхові виплати виплачуються застрахованому чи особам, які мають на це право, лише у разі настання страхового випадку. Перелік обставин, за яких настає страховий випадок, визначається Кабінетом Міністрів України. Водночас, відповідно до ч. 1 ст. 1 даного Закону, об’єктом соціального страхування є не лише страховий випадок, а й страховий ризик, із настанням якого у застрахованих осіб (членів їхніх сімей, інших осіб) виникає право на матеріальне забезпечення та соціальні послуги. Окрім того, Закон дає визначення поняття страхового ризику за соціальним страхуванням від нещасного випадку, зазначаючи, що це обставини, унаслідок яких може статися нещасний випадок. Таким чином, можемо зазначити, що законодавець, передбачивши можливість соціального страхування від ризиків, не виробив жодного механізму відшкодування потерпілому, внаслідок чого така норма $€$ декларативною і такою, яку в практичному розумінні неможливо реалізувати. 3 огляду на це, на переконання дослідників із цієї проблематики, яких ми цілком підтримуємо, слід виробити юридичний механізм матеріального забезпечення та надання соціальних послуг у разі настання страхових ризиків. Зокрема, такий механізм повинен включати: вироблення законодавчо встановленого переліку страхових ризиків; запровадження механізму фіксаціï і розслідування страхових ризиків; юридично закріплений перелік видів страхових виплат (розміри таких виплат) та соціальних послуг, порядок їх надання у разі настання страхового ризику.

Висновки. Проаналізувавши наукові підходи, законодавче регламентування категорію «загальнообов'язкове державне соціальне страхування від нещасних випадків та професійних захворювань на виробництві» слід визначити як установлену і регламен- 
товану державою систему гарантій, що передбачає матеріальне забезпечення, страхові виплати та надання соціальних послуг застрахованій особі в разі настання нещасного випадку та професійного захворювання на виробництві в процесі виконання такою особою своїх трудових обов'язків або пов'язаних із трудовими. До характерних ознак такого страхування слід віднести такі: (а) є певним захистом від настання небажаних ризиків чи наслідків; (б) є гарантією закріпленого в ст. 46 Конституції України права на соціальний захист; (в) є державним страхуванням, тобто порядок, умови здійснення визначаються і регулюються державою та не можуть змінюватися на розсуд сторін, як це може бути в приватному; (г) охоплює конкретну сферу, а саме трудову діяльність. Страхування від нещасних випадків та професійних захворювань на виробництві невіддільне від трудової діяльності та може здійснюватися лише у разі впливу на працівника небезпечного виробничого фактору чи середовища, що сталися у процесі виконання ним трудових обов'язків або пов'язаних із трудовими, унаслідок яких заподіяно шкоду здоров'ю або настала смерть; (г) переслідує певну економічну функцію, що полягає у створенні необхідних умов для відтворення трудових ресурсів; (д) обов'язковість, тобто особи, які визначені законом, повинні сплачувати внески на загальнообов'язкове соціальне страхування; (е) імовірний характер відносин, який передбачає неможливість визначення заздалегідь суб'єктного складу правовідносин, часу настання випадку, розміру виплат.

У статті розглянуто поняття та характерні ознаки, притаманні загальнообов'язковому державному соціальному страхуванню від нещасних випадків та професійних захворювань на виробниитві. Проаналізувавщи наукові підходи, законодавче регламентування, категорію «загальнообов'язкове дернавне соиіальне страхування від нещасних випадків та професійних захворювань на виробництві» запропоновано визначити як установлену $i$ регламентовану державою систему гарантій, що передбачає матеріальне забезпечення, страхові виплати та надання соціальних послуг застрахованій особі в разі настання нещасного випадку та професійного захворювання на виробництві в проиесі виконання такою особою своїх трудових обов'язків або пов'язаних із трудовими. До характерних ознак такого страхування віднесено такі: (а) є певним захистом від настання небажаних ризиків чи наслідків; (б) є гарантією закріпленого в сm. 46 Конституиіï України права на соціальний захист; (в) є державним страхуванням, тобто порядок, умови здійснення визначаються $і$ регулюються державою та не можуть змінюватися на розсуд сторін, як ие може бути в приватному; (г) охоплюе конкретну сферу, а саме трудову діяльність. Страхування від нещасних випадків та професійних захворювань на виробництві невіддільне від трудової діяльності та може здійснюватися лише у разі впливу на працівника небезпечного виробничого фактору чи середовища, щзо сталися у процесі виконання ним трудових обов'язків або пов'язаних із трудовими, унаслідок яких заподіяно шкоду здоров'ю або настала смерть; $(\tau)$ переслідує певну економічну функцію, що полягае у створенні необхідних умов для відтворення трудових ресурсів; (Ә) обов'язковість, тобто особи, які визначені законом, повинні сплачувати внески на загальнообов'язкове соціальне страхування; (е) імовірний характер відносин, який передбачає неможливість визначення заздалегідь суб'єктного складу правовідносин, часу настання випадку, розміру виплат.

Ключові слова: соціальний захист, страхування, трудова діяльність, страховий випадок, страховий ризик, нещасний випадок, професійне захворювання. 
Soroka O. Concepts and signs of social insurance against accidents and occupational diseases in production

The article considers the concepts and characteristics inherent in the mandatory state social insurance against accidents and occupational diseases at work. After analyzing scientific approaches, the legislation regulating the category of "compulsory state social insurance against accidents and occupational diseases at work" is defined as a system of guarantees established and regulated by the state, which provides material support, insurance payments and social services to the insured person in case of accident. case and occupational disease at work in the process of such person's performance of their duties or related to labor. The characteristic features of such insurance include the following: (a) there is some protection against the occurrence of undesirable risks or consequences; (b) is a guarantee enshrined in Art. 46 of the Constitution of Ukraine, the right to social protection; (c) is public insurance, ie the procedure, conditions of implementation are determined and regulated by the state and may not be changed at the discretion of the parties, as it may be in private; (d) covers a specific area, namely employment. Insurance against accidents and occupational diseases at work is inseparable from work and can be carried out only in the case of exposure of the employee to a dangerous production factor or environment that occurred in the course of his duties or related to work, resulting in harm to health. or death; (e) pursues a certain economic function, which is to create the necessary conditions for the reproduction of labor resources; (f) compulsory, ie persons required by law to pay contributions to compulsory social insurance; $(g)$ the probable nature of the relationship, which implies the impossibility of determining in advance the subjective composition of the legal relationship, the time of the case, the amount of payments.

Key words: social protection, insurance, labor activity, insured event, insurance risk, accident, occupational disease.

\section{Література}

1. Карамишев Д.В. Загальнообов'язкове державне соціальне медичне страхування в Україні: від соціального діаrогу до суспільного консенсусу. Теорія та практика державного управління. 2013. Bun. 4(43). C. 1-8.

2. Сільченко С.О. Сочіальне страхування: реалії та перспективи правового регулювання. Проблеми законності. 2009. Bun. 102. С. 78-86.

3. Гуменюк I.O. Правові основи становлення соціального страхування в Україні : автореф. дис. ... канд. юрид. наук. Харків, 2001. 19 с.

4. Вигдорчик Н.А. Теория и практика соииального страхования. Теоретические основы социального страхования. Петроград : Книга, 1919. 144 с.

5. Стеценко С.Г., Стеценкко В.Ю., Шатковський Я.М. Медичне право Украіни (правові засади забезпечення медичного страхування). Київ : Атіка, 2010. $208 \mathrm{c}$.

6. Основи законодавства України про загальнообов'язкове державне соитальне страхування : Закон України віо 14.01.1998 № 16/98-BP. Biдомості Верховної Ради Украӥни. 1998. № 23. Сm. 121.

7. Про загальнообов'язкове державне соиіальне страхування на випадок безробіття : Закон України від 02.03.2000 № 1533-III. Відомості Верховної Ради України. 2000. № 22. Cm. 171.

8. Базилевич В.Д. Страхування : підручник. Київ : Знання, 2008. 1019 с.

9. Боднарук М.I. Щодо питання ознак соитільного страхування. Митна справа. 2014. № 1 (91). С. 299-302. 